\title{
The Effect of Different Nutrition Education Approaches on Children's Nutritional Status
}

\author{
Farklı Beslenme Eğitimi Yaklaşımlarının Çocukların Beslenme Durumlarına \\ Etkisi
}

(D) Burcu ATEŞ ÖZCAN1, (D Aydan ERCAN²

1'́stanbul Okan University, Department of Nutrition and Dietetics in English, İstanbul, Turkey

${ }^{2}$ Trakya University, Department of Nutrition and Dietetics, Edirne, Turkey

\section{ABSTRACT}

Objective: The study was performed to assess the potential of different educational approaches given to primary school children on their nutritional status.

Methods: The study was conducted with all second and third-grade students studying in an elementary school. First, 2 second and thirdgrade teachers were given nutrition education by the researcher. These teachers gave a healthy nutrition education to their classes for 2 months as indirect education. During the same period, the researcher gave direct nutrition education to other students. Before all education, a questionnaire and food consumption frequency forms were tested on all students. After waiting for 2 months, the food consumption frequency form applied to the students again.

Results: While the percentage of students' energy from total fat and saturated fat was decreased at the end of the education, the percentages of energy from monounsaturated fatty acids and polyunsaturated fatty acids were increased $(p<0.05)$. The decrease in percentages of total fat and saturated fat is more efficient in indirect education $(\mathrm{p}<0.05)$. Direct nutrition education was more effective in increasing the intake of riboflavin, niacin and vitamin B12, while indirect nutritional education was more effective in increasing the intake of thiamine, A, B6, E and C vitamins ( $\mathrm{p}<0.05)$.

Conclusion: Nutrition education given to children had a positive effect on their h nutritional status. This effect was moderately better through indirect education, and we believe this is due to the fact that students considered their teachers as role models.

Keywords: Child nutrition, nutrition, nutrition education

\section{ÖZ}

Amaç: Bu çalışma, ilkokul çocuklarına verilen farklı eğitim yaklaşımlarının çocukların beslenme durumlarına etkisinin belirlenmesi amacı ile yapılmıştır.

Yöntemler: Çalışma, bir ilkokulda okuyan tüm ikinci ve üçüncü sınıf öğrencileri ile gerçekleştirilmiştir. İlk olarak, dört sınıf öğretmeninden ikisine araştırmacı tarafından beslenme eğitimi verilmiştir. Biri 2. sınıf, biri de 3. sınıfla ilgilenen bu öğretmenler, dolaylı eğitim olarak, 2 ay boyunca kendi derslerinde konu ile ilgili sağlıklı beslenme eğitimi vermişlerdir. Aynı dönemde araştırmacı, diğer öğrencilere doğrudan beslenme eğitimi vermiştir. Eğitimlerden önce tüm öğrencilerden anket ve besin tüketim sıklığı formları alınmıştır. İki ay bekledikten sonra öğrencilere tekrar besin tüketim sıklığı formu uygulanmıştır.

Bulgular: Eğitim sonunda, öğrencilerin toplam yağ ve doymuş yağdan alınan enerji yüzdesi azalırken, tekli doymamış yağ asitlerinden ve çoklu doymamış yağ asitlerinden gelen enerji yüzdeleri artmı̧şır $(\mathrm{p}<0,05)$. Toplam yağ ve doymuş yağ yüzdelerindeki azalma dolaylı eğitimde daha etkilidir $(p<0,05)$. Doğrudan beslenme eğitiminin riboflavin, niasin ve $\mathrm{B} 12$ vitamini artışlarında daha etkili olduğu, dolaylı beslenme eğitimi ise tiamin, A, B6, E ve C vitaminlerinin artış oranlarında daha etkili olduğu bulunmuştur $(\mathrm{p}<0,05)$.

Sonuç: Çocuklara verilen beslenme eğitimi, çocukların her iki durumda da beslenmeleri üzerinde olumlu bir etkiye sahiptir. Öğretmenlerin öğrenciler için rol model olması nedeniyle bu etkinin öğretmen eğitiminde 1 lımlı derecede daha çok olduğu düşünülmektedir.

Anahtar Sözcükler: Çocuk beslenmesi, beslenme, beslenme eğitimi

Address for Correspondence: Burcu ATEŞ ÖZCAN, İstanbul Okan University, Department of Nutrition and Dietetics in English, İstanbul, Turkey

E-mail: burcuates474@hotmail.com ORCID ID: orcid.org/0000-0003-2627-0167

Received: 07.06.2020

Accepted: 20.08.2020

Cite this article as: Ateş Özcan B, Ercan A. The Effect of Different Nutrition Education Approaches on Children's Nutritional Status. Bezmialem Science 2021;9(3):334-43. 


\section{Introduction}

Child nutrition directly affects their growth, development and academic performance and is closely related to the state of health in adulthood. Optimal nutrition reduces the risk of developing iron-deficiency anaemia, vitamin $\mathrm{D}$ deficiency, obesity, dental caries and chronic diseases such as diabetes, osteoporosis and heart disease (1-3). Nutritional behaviours of individuals were established in childhood $(4,5)$. It is, therefore, necessary to convey the correct information to children through nutrition education in childhood to have a positive impact. A study conducted on children and young adolescents showed that improvement of nutritional knowledge enables children to acquire better eating habits (6). For this purpose, regular nutrition education in primary, secondary and high schools is the best way to convert this information into behaviour $(2,7)$. Nutrition education is a part of applied nutrition which is implemented to improve people's health, raise awareness of individuals about healthy nutrition and lifestyle. By increasing their scientific knowledge, they will probably translate this information into a lifestyle (8). School-based nutrition education aims to promote the welfare of the community through the recognition, adoption and motivation of healthier diet and eating practices by children and possibly by their families and, therefore, by the community (9). Since the risk of many non-communicable diseases is closely related to eating habits, various diet education programmes aiming at establishing healthy eating habits in children are being implemented worldwide (4). This study was planned and conducted to determine and evaluate the effect of nutritional education given to the second and third-grade students of a selected primary school by a dietician directly or indirectly with the class teacher trained by the dietician on the nutritional status of the students.

\section{Methods}

\section{Study Design}

For this study, the Ethics Committee Approval was obtained from Başkent University Medicine and Health Sciences Research Committee with the decision of 18/09 dated 03/01/2018. The study was conducted with all the second and third-grade students studying at the same school between January 2018 and April 2018, after obtaining the necessary permissions and approval from the Okan College Primary School Directorate. The permissions for the student's attendance to the study were given by the parents. The study included students whose parents allowed their children to participate in the study, read and signed the "Parent Voluntary Consent Form". The students also read and signed the "Student Voluntary Consent Form". Students with any chronic and/or metabolic disease, taking any medication, laxative and/or stool softener, oral supplementation were not included in the study. Two students who could not come to school due to their illnesses were excluded from the study. Two students who were excluded from the study were also given nutritional education, and anthropometric measurements were taken in order not to be separated from their classmates. However, their evaluations were not included in the study.

\section{Participants and Recruitment}

There are 2 second and 2 third-grade classes at the primary school. In this study, two groups were randomly selected as 1 second class and 1 third class in each group. Nutrition education is planned to be given directly to one group and indirectly to the other group. Indirect nutritional education (TE) is defined as the education given by the teachers, second and third-grade teachers trained by the researcher and direct nutritional education (DE) is defined when it is given directly to the other students by the researcher. All teachers voluntarily participated in the study. 2 teachers from indirect education were given nutritional education.

\section{Procedures}

Before educating the students, two teachers who were in indirect education were given nutrition education twice a week (total 140 minutes) for 70 minutes each. The other two teachers did not receive any nutrition education. Educated teachers transferred their acquired nutritional knowledge to their students through their own Life Science courses. The teachers devoted a total of 1 lesson (35 minutes) per week to related topics for 4 weeks (140 minutes in total). The topics are the same as the direct nutrition education group, which is parallel to the nutrition education that teachers receive from the researcher. Teachers integrated the topics into their lessons and explained them with a visual presentation.

In direct nutrition education, students were given nutritional education by a computer-assisted visual presentation during a course ( 35 minutes) and a total of 4-course hours (total 140 minutes) by the researcher simultaneous with the indirect nutrition education. The content of nutrition education given in all classes was the same, and the subjects included were as follows: 1- Healthy Nutrition-1: definition and importance of healthy nutrition, adequate and balanced nutrition, food groups. 2- Healthy Nutrition-2: nutrients and their importance for health, the healthy plate, food selection and daily nutrition issues. 3- Healthy Nutrition in Children: the importance of child nutrition, its role in the growth and development, problems in cases of inadequacy and imbalance, adequate and balanced nutrition in children. 4- Misconceptions and Frequently asked questions. Before the educations, a questionnaire including the demographic characteristics of the students and the frequency of nutrient consumption form were applied. At the end of the two month waiting period after the educations, the frequency of food consumption status was re-evaluated in students. The questionnaire form was designed by the researcher based on the review of the literature and the face to face interview method was used in the application of the questionnaire. The questionnaire included questions about the demographic characteristics of students such as age, gender and nutritional habits such as fruit and vegetable consumption of the students. The frequency and amount of food consumption of the students were recorded in the food consumption frequency form containing 49 different food types. The daily energy and nutrients of the students were calculated through the records. These data were analysed using the Computer-Aided Nutrition Programme (Nutrition Information 
Systems Package Programme- BEBIS) developed for Turkey. The calculated energy and nutrient data were examined according to the dietary reference intake (DRI) by age and gender (10).

\section{Statistical Analysis}

Since the numbers in the groups were sufficient according to the central limit theorem for continuous data, the analyses were performed under the normal distribution approach (11).

Student's t-test was used for the comparison of two independent groups, Paired t-test was used for the comparison of two dependent groups and two-way analysis of variance was used for repetitive measurements from the general linear models to observe the change of independent groups over time. Descriptive statistics are expressed as mean, standard deviation, minimum and maximum values. For the analysis of categorical data, chisquare test was used for independent groups and Fisher Exact test was used when the number of observations less than 5 was above $20 \%$. Marginal homogeneity test was applied for the dependent data with more than two groups, and descriptive statistics were expressed with frequency and percentage. Two ratios were compared for those with significant relationships. Significance level was taken as 0.05 . Data were analysed using SPSS 21 package programme.

\section{Results}

A total of 70 students consisting of 32 females $(45.7 \%)$ and 38 males $(54.3 \%)$ with a mean age of 8.17 years $( \pm 0.68)$ participated in the study. The mean age of the DE group was 8.06 years $( \pm 0.56)$ and the mean age of the TE group was 8.26 years $( \pm 0.76)$. There was no statistically significant difference in age between the two groups ( $\mathrm{p}>0.05)$. While $15(46.9 \%)$ of the DE group were female and 17 (53.1\%) were male, 17 (44.7\%) of the TE group were female, and $21(55.3 \%)$ were male. Gender was homogeneous in the education groups $(\mathrm{p}>0.05) .42$ $(60.0 \%)$ of the students who participated in the study were in the $2^{\text {nd }}$ grade, and $28(40.0 \%)$ of them were $3^{\text {rd }}$-grade students. There was no statistically significant difference between $1^{\text {st }}$ and $2^{\text {nd }}$-grade students according to educational groups $(p>0.05)$ (Table 1). While total fat, saturated fat, monounsaturated fatty acids (MUFA) and sodium intake of all students decreased significantly $(\mathrm{p}<0.05)$, all other macro and micronutrients, except potassium, showed a significant increase $(p<0.05)$. DE was found to be more effective in riboflavin, niacin and vitamin B12 increase rates, while indirect nutritional education was more effective in increasing the consumption of thiamine, vitamins A, B6, E and C $(p<0.05)$. The amount of vegetables and fruits intake and the number of students consuming the fruit without peeling increased with education. This increase was significantly higher in the indirect nutritional education group than the direct nutrition education group $(\mathrm{p}<0.05)$.

\section{Discussion}

Childhood is the period when the learning speed is the highest. It is considered as the period in which parents and teachers have important effects on child development. It is thought that all kinds of education given to school children are more effective, permanent and those habits, attitudes and behaviours acquired during childhood are reflected in adulthood. Hence, it is

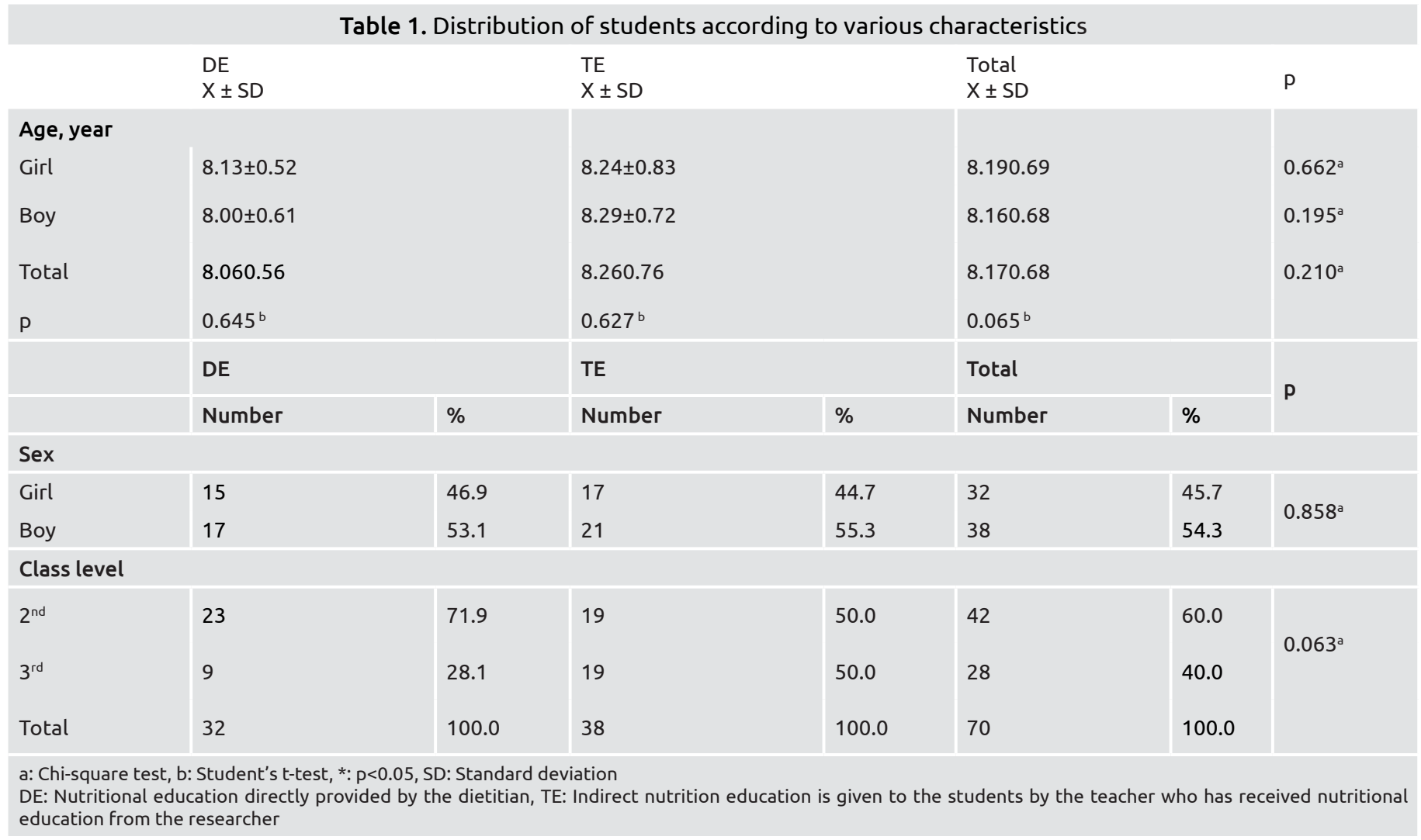


emphasised that nutrition and health education given to schoolgoing children will have far-reaching benefits for society in gaining effective and lasting habits (12-14). A diet rich in fruits and vegetables has many health benefits, such as reducing the risk of cardiovascular disease, stroke and cancer (15). The World Health Organization recommends that children should consume at least $5(400 \mathrm{~g})$ portions of vegetables and fruits per day (16).

In this study, it was seen that while the consumption of vegetables and fruits before the education was below the recommendations, there was a significant increase at the end of the education and the consumption of the students reached the recommended levels. Both direct and indirect nutritional education had a positive effect. It was determined that indirect nutrition education had a better effect on daily fruit and vegetable consumption $(\mathrm{p}<0.001)$ (Table 2). Similarly, in a study lasting 14 months, teachers were educated about healthy nutrition and physical activity and, the effect of teachers on students was examined (17). As a result of the study, there was an increase in the consumption of vegetables and fruits. In another study in which the effect of direct nutrition education given by dietitian and indirect nutrition education given by the teacher was investigated on fruit and vegetable consumption of children, similar to this study, it was observed that both direct and indirect nutrition educations increased the consumption of vegetables and fruits. Indirect nutrition education was more effective than direct nutrition education (13). According to DRI, for children aged 7-9, the recommended daily fibre intake is 25 grams (18). The Turkey-specific dietary guidelines have been reported that $55.9 \%$ of children ages 7-10 in Turkey have fibre consumption below requirements (19). These data showed that the average daily fibre intake of students before the training was below the recommended amount $(9.67 \pm 2.33)$. At the end of the education, it was observed that the average daily pulp intake of all students $(28.99 \pm 8.47)$ exceeded the recommended level. Fibre intake increased both in direct and indirect nutrition education. However, the amount of fibre intake in indirect education was above the recommendations, while it remained below the recommendations in DE (Table 2).

Increasing the daily amounts of consumption of vegetables and fruits helps to increase the amount of daily fibre intake (20). In this study, indeed, the increase in the daily fruit and vegetable consumption helped to increase the daily fibre intake of the students above the recommended level. In addition to providing nutritional diversity through a healthy diet, the ratios of energy from carbohydrates, proteins and fats must be met. According to DRI for children aged 4-18, it is recommended that $50 \%$ $60 \%$ of daily energy is supplied from carbohydrates, $25 \%-35 \%$ from fats and $10 \%-20 \%$ from proteins (18). In this study, the percentage of total energy from carbohydrates for all students before the education was noted below the recommended level. At the end of the education, the percentages for both groups met the recommendations $(\mathrm{p}<0.05)$. Before the education, the percentage of total energy from fat was $40.59 \% \pm 4.04 \%$ for all students. At the end of the educations, the percentages of these students' daily energy intake from fat were reduced to the recommended limits (TE $28.63 \% \pm 1.00 \%$, DE $31.25 \% \pm 3.28 \%$ ), $(\mathrm{p}<0.001)$. The percentage of daily energy intake from protein was found to be higher in TE group than $\mathrm{n}$ the direct nutrition education group $(p<0.001)$. In healthy nutrition, the type of fat should be carefully examined as well as the ratio of energy from fat. It is recommended that the energy from the total fat taken from the diet is less than $8 \%$ for saturated fat, $10 \%-15 \%$ for MUFA and 6\%-10\% for polyunsaturated fats (PUFA). In total fat intake, the rate of energy from $n-6$ should be limited to $4 \%-$ $13 \%$ and the rate from $n-3$ to $1 \%-2 \%$ (21). In this study, it was seen that the percentage of students' dietary energy from saturated fat was higher than the recommended levels in both direct and indirect education. But the percentage values at the end of the educations were significantly lower than previous ones (for all groups $\mathrm{p}<0.001$ ). The percentage of the energy coming above-recommended level of saturated fat occurs probably, due to students' preference for animal-based foods as protein sources for increasing the protein intake. This, in turn, increased the saturated fat intake. Indirect nutrition education was found to be more effective in reducing the percentage of energy from saturated fat than direct nutrition education $(\mathrm{p}<0.001)$. The percentages of students' energy coming from the PUFA were lower than the recommended levels and after the education, and this was increased in all groups. Direct training was found to be more effective in this increase $(\mathrm{p}<0.05)$. While the percentage of

\begin{tabular}{|c|c|c|c|c|c|c|c|c|}
\hline & $\mathrm{DE}$ & & TE & & Total & & & \\
\hline & $X \pm S D$ & Min-max & $X \pm S D$ & Min-max & $\mathrm{X} \pm \mathrm{SD}$ & Min-max & $P_{t}$ & $\mathrm{P}_{\mathrm{GLM}}$ \\
\hline \multicolumn{9}{|c|}{ Vegetable-fruit portion consumed daily } \\
\hline $\begin{array}{l}\text { Before education } \\
\text { After education }\end{array}$ & $\begin{array}{l}1.37 \pm 0.83 \\
4.75 \pm 0.67\end{array}$ & $\begin{array}{l}0.30-4.00 \\
3.00-6.00\end{array}$ & $\begin{array}{l}1.32 \pm 0.72 \\
6.79 \pm 1.23\end{array}$ & $\begin{array}{l}0.40-3.00 \\
5.00-9.00\end{array}$ & $\begin{array}{l}1.34 \pm 0.77 \\
5.86 \pm 1.44\end{array}$ & $\begin{array}{l}0.30-4.00 \\
3.00-9.00\end{array}$ & $\begin{array}{l}0.787 \\
<0.001 * *\end{array}$ & $<0.001 * *$ \\
\hline $\mathrm{P}_{\text {pair }}$ & \multicolumn{2}{|l|}{$<0.001^{* *}$} & \multicolumn{2}{|l|}{$<0.001 * *$} & \multicolumn{2}{|l|}{$<0.001 * *$} & & \\
\hline \multicolumn{9}{|c|}{ The daily amount of fibre intake ( $\mathrm{g}$ ) } \\
\hline $\begin{array}{l}\text { Before education } \\
\text { After education }\end{array}$ & $\begin{array}{l}10.82 \pm 2.60 \\
22.92 \pm 7.96\end{array}$ & $\begin{array}{l}7.10-21.40 \\
12.00-44.20\end{array}$ & $\begin{array}{l}8.70 \pm 1.53 \\
34.11 \pm 4.71\end{array}$ & $\begin{array}{l}6.50-12.00 \\
26.51-45.10\end{array}$ & $\begin{array}{l}9.67 \pm 2.33 \\
28.99 \pm 8.47\end{array}$ & $\begin{array}{l}6.50-21.40 \\
12.00-45.100\end{array}$ & $\begin{array}{l}<0.001 * * \\
<0.001 * *\end{array}$ & $<0.001 * *$ \\
\hline $\mathrm{P}_{\text {pair }}$ & $<0.001^{* *}$ & & $<0.001^{* *}$ & & $<0.001 * *$ & & & \\
\hline
\end{tabular}

$\mathrm{P}_{\text {pair }}$ : Paired t-test, $\mathrm{P}_{\mathrm{t}}$ : Student's t-test, $\mathrm{P}_{\mathrm{GLM}}$ : Two-way analysis of variance for repeated measurements from general linear models (GLM) *: $\mathrm{p}<0.05, * *: \mathrm{p}<0.001, \mathrm{SD}$ : Standard deviation, Min: Minimum, Max: Maximum 
students' daily energy from $\mathrm{n}-6$ was within the recommended levels before and after the education, a significant increase was observed in all groups at the end. While the percentages of energy from $\mathrm{n}-3$ were below the recommendations in all groups before the educations, it was increased to the recommended level at the end (for all groups $p<0.001$ ). The ratio of energy from $\mathrm{n}-3$ fatty acids is higher in the direct nutrition education group $(1.46 \% \pm 0.24 \%)$ than in TE group $(1.34 \% \pm 0.24 \%)(\mathrm{p}<0.05)$ (Table 3).

Vitamins and minerals, which are very important for the body, contribute to the growth and development and play an essential role in many biological processes such as energy metabolism, bone formation and preservation, blood production, immune system, maintenance of normal functions of the body cells and prevention of damage (22). In this study, while the levels of vitamin $\mathrm{E}$, thiamine, calcium and iron of nutrition education students given both directly and indirectly were lower than the recommended levels, the levels of the two groups reached the reference values at the end of the education $(p<0.001)$. In both groups, vitamin A, riboflavin, niacin, vitamin B6, vitamin B12, phosphorus, zinc and magnesium levels were found to be within normal ranges before the education and all the values were increased at the end. Regarding the increase in vitamins and minerals at the end of the education, indirect nutrition education was more effective for vitamin $\mathrm{E}$, vitamin $\mathrm{A}$, vitamin C, vitamin B6, thiamine, calcium, iron, phosphorus, magnesium and direct nutrition education was found to be more effective for

Table 3. Average energy, macro and micro nutrients of the students by diet

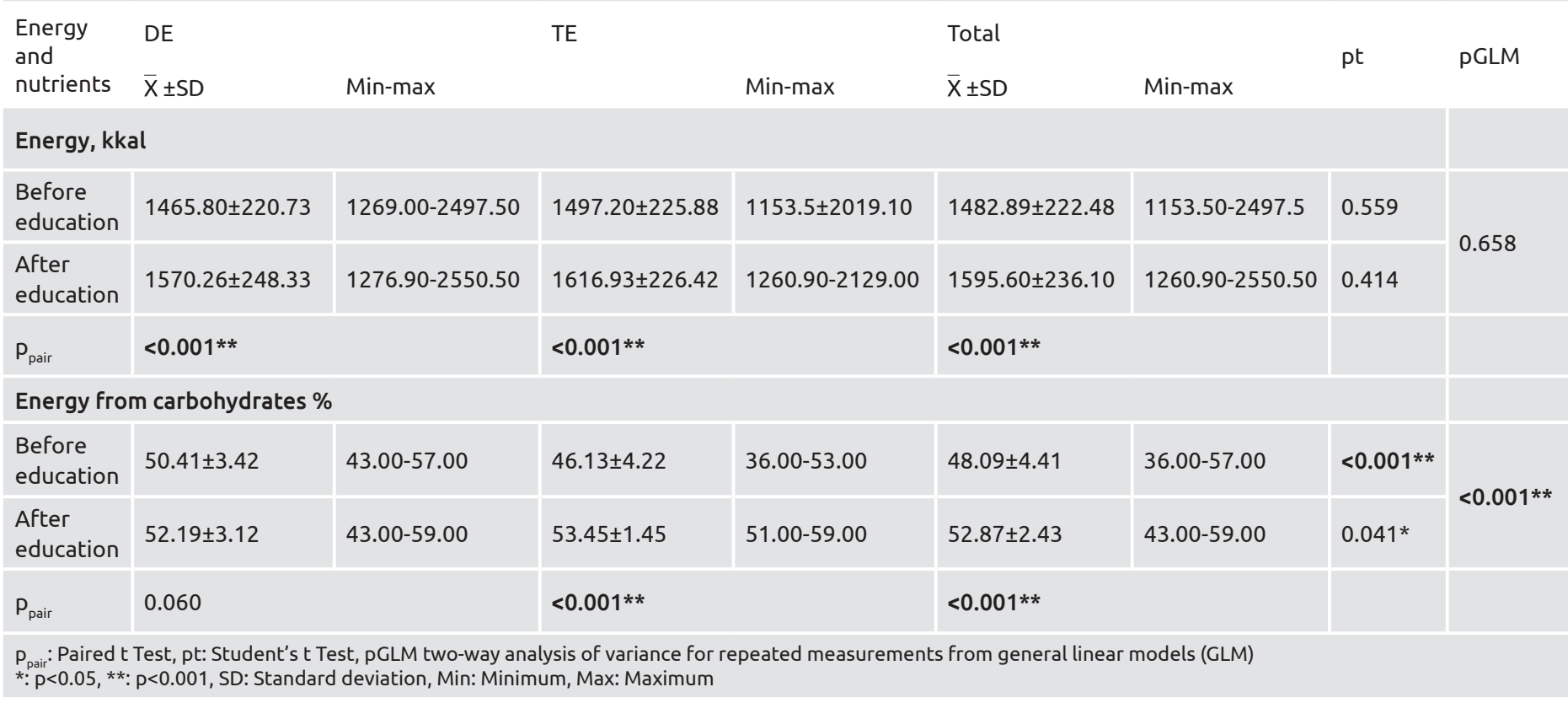

Table 3. Average energy, macro and micronutrients of the students by diet (cont.)

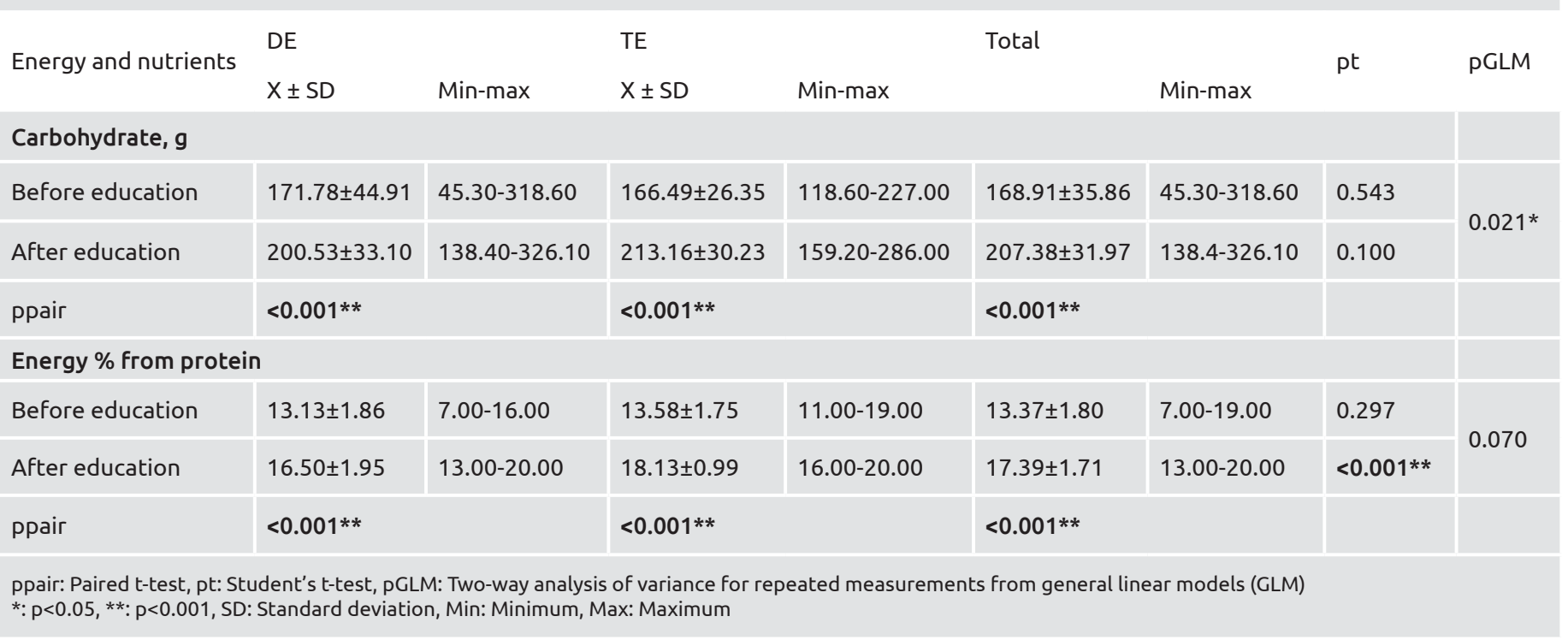


riboflavin, niacin, B12 and zinc. In TE group, all vitamin and mineral levels except B12, potassium and zinc were found to be higher at the end. In a study, the nutrient intake of 146 female students aged 10-16 years was examined. It was observed that the average energy, protein, total fat, calcium, iron, vitamin A, riboflavin, niacin and vitamin $\mathrm{C}$ intake of the students were lower than the RDA (recommended daily intake level) (23). Nutrition education in children provides a significant positive impact on nutritional knowledge, nutritional behaviours and eating habits $(24,25)$. In a study conducted with 72 female students

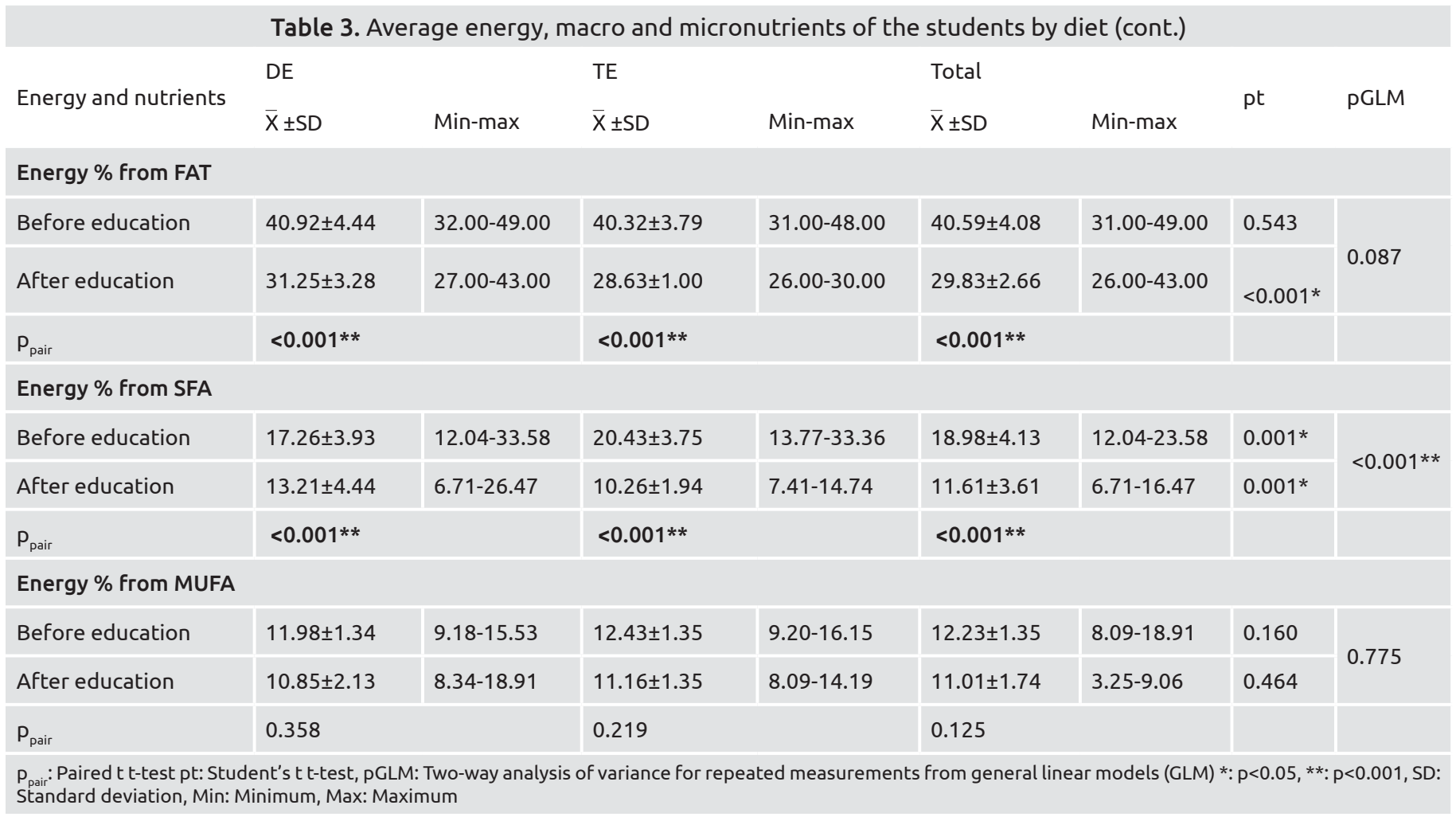

Table 3. Average energy, macro and micronutrients of the students by diet (cont.)

\begin{tabular}{|c|c|c|c|c|c|c|c|c|}
\hline Energy and nutrients & \multicolumn{2}{|l|}{$\mathrm{DE}$} & \multicolumn{2}{|l|}{ ÖE } & \multicolumn{2}{|l|}{ Total } & pt & pGLM \\
\hline \multicolumn{9}{|l|}{ Energy \% from PUFA } \\
\hline Before education & $4.89 \pm 1.09$ & $3.25-9.06$ & $4.85 \pm 0.62$ & $3.93-6.76$ & $4.87 \pm 0.86$ & $3.25-9.06$ & 0.822 & \multirow{2}{*}{0.418} \\
\hline After education & $5.63 \pm 1.80$ & $3.96-12.81$ & $5.36 \pm 0.88$ & $4.38-7.82$ & $5.48 \pm 1.37$ & $3.96-12.81$ & 0.428 & \\
\hline \multicolumn{9}{|l|}{ Energy \% from n-3 } \\
\hline Before education & $0.85 \pm 0.38$ & $0.51-2.69$ & $0.94 \pm 0.19$ & $0.63-1.47$ & $0.90 \pm 0.30$ & $0.51-2.69$ & 0.188 & \multirow{2}{*}{0.715} \\
\hline After education & $1.34 \pm 0.24$ & $0.83-1.96$ & $1.46 \pm 0.24$ & $1.03-1.86$ & $1.41 \pm 0.24$ & $0.83-1.96$ & $0.033^{*}$ & \\
\hline $\mathrm{P}_{\text {pair }}$ & \multicolumn{2}{|l|}{$<0.001 * *$} & \multicolumn{2}{|l|}{$<0.001 * *$} & \multicolumn{2}{|l|}{$<0.001 * *$} & & \\
\hline \multicolumn{9}{|l|}{ Energy \% from n-6 } \\
\hline After education & $5.03 \pm 1.77$ & $2.53-10.11$ & $4.92 \pm 1.50$ & $3.13-9.92$ & $4.97 \pm 1.62$ & $2.53-10.11$ & 0.778 & - \\
\hline ppair & $<0.001 * *$ & & $<0.001 * *$ & & $<0.001 * *$ & & & \\
\hline
\end{tabular}


Table 3. Average energy, macro and micronutrients of the students by diet (cont.)

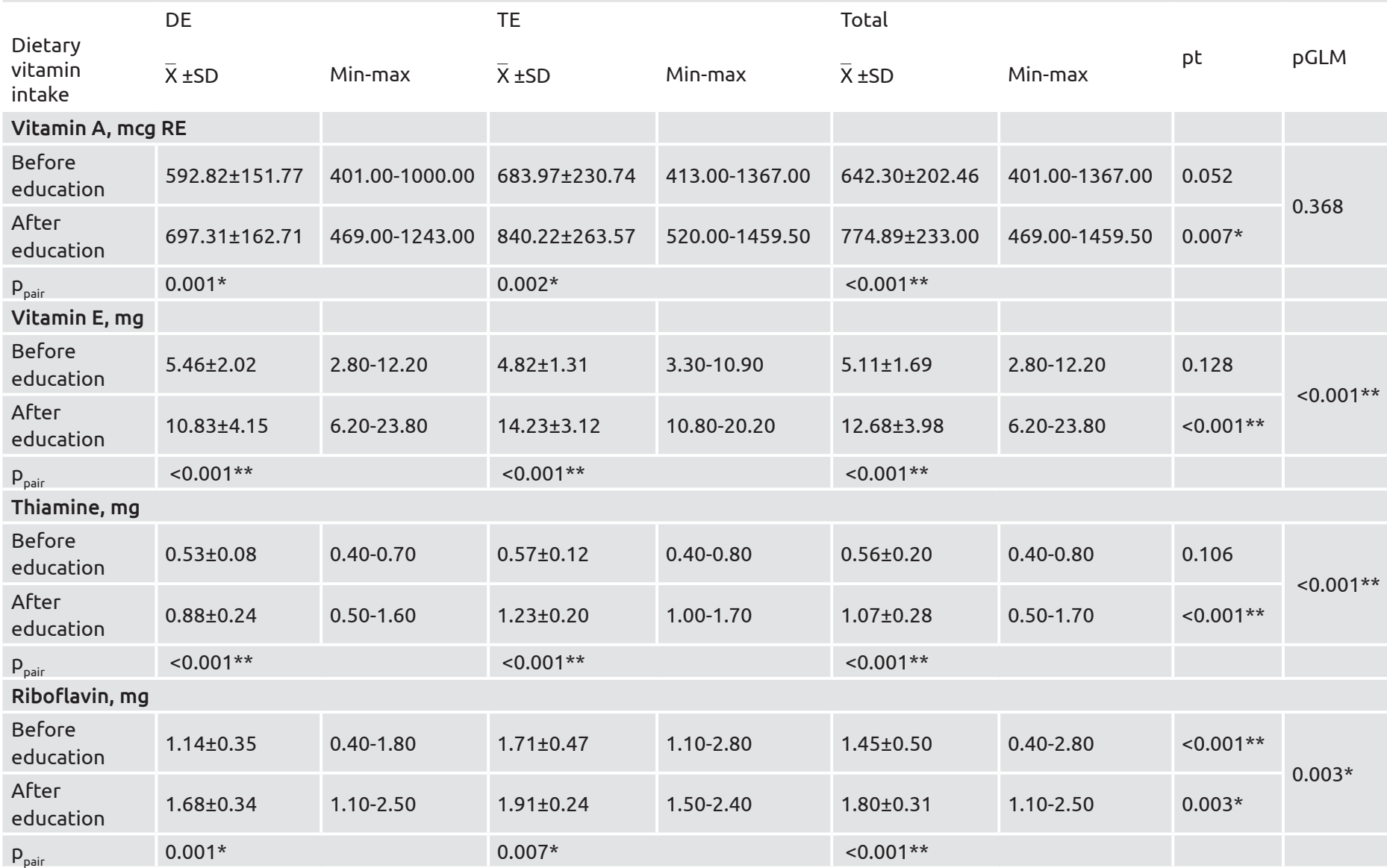

$P_{\text {pair }}$ : Paired t-test $p t:$ Student's t-test pGLM: Two-way analysis of variance for repeated measurements from general linear models (GLM), *: $p<0.05, * *: p<0.001$, SD: Standard deviation, Min: Minimum, Max: Maximum

Table 3. Average energy, macro and micronutrients of the students by diet (cont.)

\begin{tabular}{|c|c|c|c|c|c|c|c|c|}
\hline \multirow{2}{*}{$\begin{array}{l}\text { Dietary vitamin } \\
\text { intake }\end{array}$} & \multicolumn{2}{|l|}{$\mathrm{DE}$} & \multicolumn{2}{|l|}{ TE } & \multicolumn{2}{|l|}{ Total } & \multirow{2}{*}{ pt } & \multirow{2}{*}{ pGLM } \\
\hline & $\overline{\mathrm{X}} \pm \mathrm{SD}$ & Min-max & $\overline{\mathrm{X}} \pm \mathrm{SD}$ & Min-max & $\bar{X} \pm S D$ & Min-max & & \\
\hline \multicolumn{9}{|l|}{ Niacin, mg } \\
\hline Before education & $8.15 \pm 2.01$ & $3.90-11.00$ & $10.90 \pm 3.18$ & $7.70-19.00$ & $9.64 \pm 3.02$ & $3.90-19.00$ & $<0.001 * *$ & \multirow{2}{*}{0.248} \\
\hline After education & $10.58 \pm 3.28$ & $6.90-17.40$ & $12.25 \pm 1.99$ & $9.00-15.90$ & $11.49 \pm 2.77$ & $6.90-17.40$ & $0.016^{*}$ & \\
\hline $\mathrm{P}_{\text {pair }}$ & \multicolumn{2}{|l|}{$<0.001 * *$} & \multicolumn{2}{|l|}{$0.036^{*}$} & \multicolumn{2}{|l|}{$<0.001 * *$} & & \\
\hline \multicolumn{9}{|l|}{ Vitamin B6, mg } \\
\hline Before education & $0.85 \pm 0.21$ & $0.40-1.20$ & $1.08 \pm 0.26$ & $0.80-1.70$ & $0.98 \pm 0.26$ & $0.40-1.70$ & $<0.001 * *$ & \multirow{2}{*}{$0.024^{*}$} \\
\hline After education & $1.29 \pm 0.31$ & $0.90-2.10$ & $1.69 \pm 0.22$ & $1.40-2.20$ & $1.51 \pm 0.33$ & $0.90-2.20$ & $<0.001 * *$ & \\
\hline $\mathrm{P}_{\text {pair }}$ & \multicolumn{2}{|l|}{$<0.001 * *$} & \multicolumn{2}{|l|}{$<0.001 * *$} & \multicolumn{2}{|l|}{$<0.001 * *$} & & \\
\hline \multicolumn{9}{|l|}{ Vitamin C, mg } \\
\hline Before education & $58.35 \pm 18.05$ & $20.30-87.40$ & $68.47 \pm 16.13$ & $49.50-109.90$ & $63.84 \pm 17.66$ & 20.30-109.90 & $0.016^{*}$ & \\
\hline After education & $99.87 \pm 30.48$ & $47.10-158.70$ & $145.03 \pm 20.46$ & $120.50-190.90$ & $124.38 \pm 33.99$ & $47.10-190.90$ & $<0.001^{* *}$ & $<0.001 * *$ \\
\hline$P_{\text {pair }}$ & \multicolumn{2}{|l|}{$<0.001 * *$} & \multicolumn{2}{|l|}{$<0.001 * *$} & \multicolumn{2}{|l|}{$<0.001 * *$} & & \\
\hline \multicolumn{9}{|l|}{ Vitamin B12, mcg } \\
\hline Before education & $1.31 \pm 0.30$ & $0.90-2.10$ & $1.22 \pm 0.25$ & $0.87-1.70$ & $1.26 \pm 0.27$ & $0.87-2.10$ & 0.154 & \multirow{2}{*}{0.385} \\
\hline After education & $2.82 \pm 0.99$ & $1.40-4.50$ & $2.56 \pm 0.50$ & $1.70-4.10$ & $2.68 \pm 0.77$ & $1.40-4.5$ & 0.178 & \\
\hline$P_{\text {pair }}$ & \multicolumn{2}{|l|}{$<0.001 * *$} & \multicolumn{2}{|l|}{$<0.001 * *$} & \multicolumn{2}{|l|}{$<0.001 * *$} & & \\
\hline
\end{tabular}


Table 3. Average energy, macro and micronutrients of the students by diet (cont.)

\begin{tabular}{|c|c|c|c|c|c|c|c|c|}
\hline \multirow{2}{*}{$\begin{array}{l}\text { Dietary } \\
\text { mineral } \\
\text { intake }\end{array}$} & \multicolumn{2}{|l|}{$\mathrm{DE}$} & \multicolumn{2}{|l|}{ TE } & \multicolumn{2}{|l|}{ Total } & \multirow{2}{*}{ pt } & \multirow{2}{*}{ pGLM } \\
\hline & $\overline{\mathrm{X}} \pm \mathrm{SD}$ & Min-max & $\bar{X} \pm S D$ & Min-max & $\bar{X} \pm S D$ & Min-max & & \\
\hline \multicolumn{9}{|l|}{ Sodium, mg } \\
\hline $\begin{array}{l}\text { Before } \\
\text { education }\end{array}$ & $2375.51 \pm 511.67$ & $1356.70-3468.40$ & $2025.97 \pm 578.02$ & $1313.80-3610.20$ & $2185.76 \pm 572.31$ & $1313.80-3610.20$ & $0.010 *$ & \multirow{3}{*}{$0.009 *$} \\
\hline $\begin{array}{l}\text { After } \\
\text { education }\end{array}$ & $1685.88 \pm 204.38$ & $1446.00-2456.10$ & $1719.71 \pm 101.43$ & $1538.00-2898.00$ & $1704.24 \pm 156.76$ & $1446.00-2456.10$ & 0.399 & \\
\hline $\mathrm{P}_{\text {pair }}$ & \multicolumn{2}{|l|}{$0.001 * *$} & \multicolumn{2}{|l|}{$0.003^{*}$} & \multicolumn{2}{|l|}{$<0.001 * *$} & & \\
\hline \multicolumn{9}{|c|}{ Potassium, mg } \\
\hline $\begin{array}{l}\text { Before } \\
\text { education }\end{array}$ & $4363.16 \pm 565.66$ & $3199.00-5565.00$ & $4021.71 \pm 299.97$ & $3294.00-4744.00$ & $4177.80 \pm 470.49$ & $3199.00-5565.00$ & $0.004^{*}$ & \\
\hline $\begin{array}{l}\text { After } \\
\text { education }\end{array}$ & $4258.65 \pm 667.41$ & $3014.80-5206.40$ & $4173.05 \pm 632.00$ & $3056.70-5301.00$ & $4212.18 \pm 645.10$ & $3014.80-5301.00$ & 0.584 & \\
\hline$P_{\text {pair }}$ & \multicolumn{2}{|l|}{0.440} & \multicolumn{2}{|l|}{0.171} & \multicolumn{2}{|l|}{0.689} & & \\
\hline \multicolumn{9}{|c|}{ Calcium, mg } \\
\hline $\begin{array}{l}\text { Before } \\
\text { education }\end{array}$ & $492.61 \pm 107.33$ & $156.60-659.60$ & $539.94 \pm 147.41$ & $299.50-884.80$ & $518.30 \pm 131.88$ & $156.60-884.80$ & 0.126 & \multirow{2}{*}{0.075} \\
\hline $\begin{array}{l}\text { After } \\
\text { education }\end{array}$ & $998.70 \pm 215.09$ & $562.80-1447.00$ & $1138.56 \pm 133.24$ & $860.30-1413.50$ & $1074.62 \pm 187.70$ & $562.80-1447.00$ & $0.002^{*}$ & \\
\hline $\mathrm{P}_{\text {pair }}$ & \multicolumn{2}{|l|}{$<0.001 * *$} & \multicolumn{2}{|l|}{$<0.001 * *$} & \multicolumn{2}{|l|}{$<0.001 * *$} & & \\
\hline \multicolumn{9}{|l|}{ Iron, mg } \\
\hline $\begin{array}{l}\text { Before } \\
\text { education }\end{array}$ & $7.82 \pm 1.14$ & $5.60-10.70$ & $8.43 \pm 1.77$ & $6.50-12.80$ & $8.15 \pm 1.54$ & $5.60-12.80$ & 0.089 & \multirow{2}{*}{$<0.001 * *$} \\
\hline $\begin{array}{l}\text { After } \\
\text { education }\end{array}$ & $10.96 \pm 3.07$ & $6.30-19.10$ & $14.86 \pm 1.88$ & $11.70-19.40$ & $13.08 \pm 3.16$ & $6.30-19.40$ & $<0.001 * *$ & \\
\hline $\mathrm{P}_{\text {pair }}$ & \multicolumn{2}{|l|}{$<0.001 * *$} & \multicolumn{2}{|l|}{$<0.001 * *$} & \multicolumn{2}{|l|}{$<0.001 * *$} & & \\
\hline
\end{tabular}

attending primary school, 4-step nutrition education was given to the students, and a questionnaire was tested before and 2 months after the education. As a result, it was seen that students' knowledge, attitudes and behaviours improved positively with education (2). Similarly, another study that provided a nutrition education programme to 64 low-income school children for 13 weeks showed that children had positive behavioural changes after education (26). At the school-going age, students spend long hours in school. They are in constant contact with their teachers, and in the process, students take their teachers as role models. Therefore, it is very important to carry out advanced school-based nutrition education. Besides, whether the teachers are interested in the subject is important regarding their impact on the students $(14,27)$. That is why teacher education curricula should include detailed nutrition and wellness education courses. Thus currently working teachers participating in inservice training programmes organised by nutrition experts can be ensured.

\section{Study Limitations}

The difference in teachers' interest in nutrition is the most restrictive factor of the study. The teacher must have an interest in education, the enthusiasm to turn this information into a lifestyle, and the ability to transfer it to students. In our study, although the teachers were thought to be effective in this respect, the results would have been different if they had exerted more effort. Studies in which teachers' nutritional knowledge and behaviour change can be detected will form more precise judgements on this result.

\section{Conclusion}

An adequate and balanced diet is very important for children to ensure their growth and development. Diseases that develop as a result of unhealthy diet and poor lifestyle progress over time, affecting their health negatively. Gaining healthy eating habits delays and/or eliminates the risk of developing adulthood diseases. Nutrition is a lifestyle, and it needs to be integrated into life from childhood. Since the experiences gained in childhood are reflected in adulthood, it is necessary to practice and teach children adequate and balanced nutrition and a healthy lifestyle. Therefore, nutritional education programmes for school-age children are needed, and these programmes must be available across the country to see socially positive results. 
Table 3. Average energy, macro and micronutrients the students by diet (cont.)

\begin{tabular}{|c|c|c|c|c|c|c|c|c|}
\hline \multirow{2}{*}{$\begin{array}{l}\text { Dietary } \\
\text { mineral } \\
\text { intake }\end{array}$} & \multicolumn{2}{|l|}{$\mathrm{DE}$} & \multicolumn{2}{|l|}{ TE } & \multicolumn{4}{|l|}{ Total } \\
\hline & $\bar{X} \pm S D$ & Min-max & $\overline{\mathrm{X}} \pm \mathrm{SD}$ & Min-max & $\overline{\mathrm{X}} \pm \mathrm{SD}$ & Min-max & pt & pGLM \\
\hline \multicolumn{9}{|c|}{ Phosphorus, mg } \\
\hline $\begin{array}{l}\text { Before } \\
\text { education }\end{array}$ & $719.47 \pm 109.11$ & $353.80-914.70$ & $776.71 \pm 163.16$ & $572.40-1095.00$ & $750.54 \pm 143.00$ & $353.80-1095.00$ & 0.085 & \multirow{2}{*}{$<0.001^{* *}$} \\
\hline $\begin{array}{l}\text { After } \\
\text { education }\end{array}$ & $1334.19 \pm 368.34$ & $756.10-2350.70$ & $1718.07 \pm 215.82$ & $1360.60-2194.30$ & $1542.58 \pm 350.76$ & $756.10-2350.70$ & $<0.001 * *$ & \\
\hline $\mathrm{P}_{\text {pair }}$ & \multicolumn{2}{|l|}{$<0.001^{* *}$} & \multicolumn{2}{|l|}{$<0.001 * *$} & \multicolumn{2}{|l|}{$<0.001^{* *}$} & & \\
\hline \multicolumn{9}{|l|}{ Zinch, mg } \\
\hline $\begin{array}{l}\text { Before } \\
\text { education }\end{array}$ & $7.62 \pm 1.31$ & $4.50-10.20$ & $7.99 \pm 1.30$ & $6.10-11.90$ & $7.82 \pm 1.31$ & $4.50-11.90$ & 0.235 & \multirow{2}{*}{$0.017^{*}$} \\
\hline $\begin{array}{l}\text { After } \\
\text { education }\end{array}$ & $10.87 \pm 1.04$ & $7.80-12.30$ & $10.29 \pm 0.91$ & $8.70-11.90$ & $10.55 \pm 1.01$ & $7.80-12.30$ & $0.016^{*}$ & \\
\hline$P_{\text {pair }}$ & \multicolumn{2}{|l|}{$<0.001 * *$} & \multicolumn{2}{|l|}{$<0.001 * *$} & \multicolumn{2}{|l|}{$<0.001 * *$} & & \\
\hline \multicolumn{9}{|c|}{ Magnesium, mg } \\
\hline $\begin{array}{l}\text { Before } \\
\text { education }\end{array}$ & $241.80 \pm 22.35$ & $141.90-241.00$ & $268.98 \pm 45.45$ & $121.20-389.00$ & $256.56 \pm 38.96$ & 205.70-389.00 & $0.002^{*}$ & \multirow{2}{*}{$<0.001 * *$} \\
\hline $\begin{array}{l}\text { After } \\
\text { education }\end{array}$ & $350.09 \pm 84.60$ & $220.70-590.70$ & $478.64 \pm 60.11$ & $371.70-601.50$ & $419.88 \pm 96.51$ & $220.70-601.50$ & $<0.001 * *$ & \\
\hline$P_{\text {pair }}$ & \multicolumn{2}{|l|}{$<0.001 * *$} & \multicolumn{2}{|l|}{$<0.001 * *$} & \multicolumn{2}{|l|}{$<0.001 * *$} & & \\
\hline
\end{tabular}

Schools and teachers have great responsibilities in educating the children with healthy eating and lifestyle habits. School children who spend most of the day at the school also meet their nutritional needs at the school. Meanwhile, they remain under the influence of their fellow students and teachers. Interestingly, $2^{\text {nd }}$ and $3^{\text {rd }}$ year students from primary school also take their teachers as role models, and it affects their nutrition and lifestyle. For this reason, awareness-raising education should be given to developing a healthy diet and quality lifestyle. Furthermore, education should be organised to create and increase the knowledge of teachers on these issues.

\section{Ethics}

Ethics Committee Approval: Ethics committee approval was obtained from Baskent University Institutional Review Board and Ethics Committee for this study $(2018,18 / 9)$.

Informed Consent: Informed consent form has been signed.

Peer-review: Externally peer reviewed.

\section{Authorship Contributions}

Surgical and Medical Practices: B.A.Ö., Concept: B.A.Ö., A.E., Design: B.A.Ö., A.E., Data Collection or Processing: B.A.Ö., Analysis or Interpretation: B.A.Ö., Literature Search: B.A.Ö., Writing: B.A.Ö., A.E.

Conflict of Interest: No conflict of interest was declared by the authors.
Financial Disclosure: The authors declared that this study received no financial support.

\section{References}

1. Bartleman J. Infant and child nutrition. Medicine 2019;47:195-8.

2. Vardanjani AE, Reisi M, Javadzade H, Pour ZG, Tavassoli E. The Effect of nutrition education on knowledge, attitude, and performance about junk food consumption among students of female primary schools. J Educ Health Promot 2015;4:53.

3. Hayes D, Contento IR, Weekly C. Position of the Academy of Nutrition and Dietetics, Society for Nutrition Education and Behavior, and School Nutrition Association: Comprehensive Nutrition Programs and Services in Schools. J Acad Nutr Diet 2018;118:913-9.

4. Asakura K, Todoriki H, Sasaki S. Relationship between nutrition knowledge and dietary intake among primary school children in Japan: Combined effect of children's and their guardians' knowledge. J Epidemiol 2017;27:483-91.

5. Carraway-Stage V, Hovland J, Showers C, Díaz S, Duffrin MW. Food-based science curriculum yields gains in nutrition knowledge. J Sch Health 2015;85:231-40.

6. Grosso G, Mistretta A, Turconi G, Cena H, Roggi C, Galvano F. Nutrition knowledge and other determinants of food intake and lifestyle habits in children and young adolescents living in a rural area of Sicily, South Italy. Public Health Nutr 2013;16:1827-36.

7. Silveira JA, Taddei JA, Guerra PH, Nobre MR. Effectiveness of school-based nutrition education interventions to prevent and reduce 
excessive weight gain in children and adolescents: a systematic review. J Pediatr (Rio J) 2011;87:382-92.

8. McNulty J. Challenges and issues in nutrition education. Rome: Nutrition Education and Consumer Awareness Group, Food and Agriculture Organization of the United Nations. 2013. Available at: www.fao.org/ag/humannutrition/nutritioneducation/en/ Accessed: 08.08.2019.

9. FAO and United Arab Emirates University. Stepping up school-based food and nutrition education: Exploring challenges, finding solutions and building partnerships. Rome, 2019. 128 pp. Available at: http:// www.fao.org/3/CA3063EN/CA3063EN.pdf. Accessed: 08.08.2019.

10. Dietary Reference Intakes. Available at: (http://ods.od.nih.gov/ Health_Information/ Dietary_Reference_Intakes.aspx). Accessed: 29.05.2020.

11. Norman G. Likert scales, levels of measurement and the "laws" of statistics. Adv Health Sci Educ Theory Pract 2010;15:625-32.

12. Lanigan J, Bailey R, Jackson AMT, Shea V. Child-Centered Nutrition Phrases Plus Repeated Exposure Increase Preschoolers' Consumption of Healthful Foods, but Not Liking or Willingness to Try. J Nutr Educ Behav 2019;51:519-27.

13. Panunzio MF, Antoniciello A, Pisano A, Dalton S. Nutrition education intervention by teachers may promote fruit and vegetable consumption in Italian students. Nutrition Research 2007;27:524-8.

14. Pérez-Rodrigo C, Aranceta J. Nutrition education in schools: experiences and challenges. Eur J Clin Nutr 2003;57:82-5.

15. Upton D, Upton P, Taylor C. Fruit and vegetable intake of primary school children: a study of school meals. J Hum Nutr Diet 2012;25:557-62.

16. Joint WHO/FAO Workshop on Fruit and Vegetables for Health. Japan, September 2004. Available from: https://www.who.int/ dietphysicalactivity/fruit/en/ Accessed: 10.08.2019.

17. Datar A, Sturm R. Physical education in elementary school and body mass index: evidence from the early childhood longitudinal study. Am J Public Health 2004;94:1501-6.
18. Institute of Medicine. Dietary Reference Intakes for Energy, Carbohydrate, Fiber, Fat, Fatty Acids, Cholesterol, Protein, and Amino Acids. Washington, DC: The National Academies Press, 2005. Available at: https://doi.org/10.17226/10490. Accessed: 10.08.2019.

19. Turkey Dietary Guidelines, Ministry of Health of Turkey Publication No: 1046, Ankara 2016. Available at: https://dosyasb.saglik.gov.tr/ Eklenti/10922,17ocaktuberingilizcepdf.pdf?0 Accessed: 10.08.2019.

20. Ateş Özcan B, Saka M. Evaluation of fiber, fluid and vitamin mineral intakes of adult individuals with functional constipation. Journal of Nutrition and Dietetics 2018;46:220-9.

21. Uauy R, Dangour AD. Fat and fatty acid requirements and recommendations for infants of 0-2 years and children of 2-18 years. Ann Nutr Metab 2009;55:76-96.

22. Mahan LK, Raymond JL. Krause's food \& nutrition care process. 14th Edition. Saunders, 2016.

23. Goyle A, Yanenedra I. Nutrient Intakes of young girls studying in a Government School in Jaipur City. J Hum Ecol 2009;25:127-32.

24. Reinehr T, Kersting DM, Chahda C, Wollenhaupt A, Andler W. Nutritional knowledge of obese and nonobese children. J Pediatr Gastroenterol Nutr 2001;33:351.

25. Stevens J, Cornell CE, Story M, French SA, Levin S, Becenti A, et al. Development of a questionnaire to assess knowledge, attitudes, and behaviors in American Indian children. Am J Clin Nutr 1999;69:77381.

26. Balestracci K, Sebelia L, Greene G, Moore A, Chappell K, Tovar A. Perceptions of Low-Income Students Completing a Nutrition Education Program. J Nutr Educ Behav 2019;51:834-42.

27. Katsagoni CN, Apostolou A, Georgoulis M, Psarra G, Bathrellou E, Filippou C, et al. Schoolteachers' Nutrition Knowledge, Beliefs, and Attitudes Before and After an E-Learning Program. J Nutr Educ Behav 2019;51:1088-98. 